\title{
Evaluation of the Efficacy of Essential Oil Mouthwash on Oral Malodour and Periodontal Status in Patient with Special Needs
}

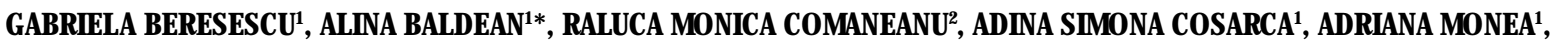
ALINA ORMENISAN ${ }^{1}$

IUniversity of Medicine, Pharmacy, Science and Technology of Tirgu-Mures, 38 Gh. Marinescu Str., 540139, Tirgu-Mures, Romania ${ }^{2}$ Titu Maiorescu University of Bucharest, Faculty of Dental Medicine, 67A Gh. Petrascu Str., 031593, Bucharest, Romania

Oral malodour is the general term used to describe disagreeable odor in expired air with psychological component in patients with special needs. The aim of this study is to evaluate the effect of essential oil mouthwash on oral halitosis and periodontal status of patient with special needs. 26 patients aged between 16-45 were enrolled in this single-blind, parallel-group study. Informed consent was obtained. The following parameters were recorded: gingival index, plaque index, organoleptic breath assessment, and BANA test from tongue coating samples prior to treatment with essential oil mouthwash (group 1) or a placebo (group 2 ) at baseline and 28 days after the start of treatment. There were significant differences $(p<0.05)$ in plaque and gingival index after treatment with essential oil mouthwash compared to the placebo. The results provide a statistically significantly greater level of efficacy in controlling established plaque and gingival index after use of essential oil mouthwash. Therefore, it can be recommended in halitosis therapy in order to maintain a good periodontal status.
\end{abstract}

Keywords: periodontal status, halitosis, essential oil, organoleptic breath, BANA test.

The term halitosis comes from Latine halitusosis meaning the pathologically modified air breath out [1,2]. Oral malodour specifically refers to such odour originating from the oral cavity itself [3]. The symptoms as a multifactorial ethology, however the most important cause is considered to be the decomposition of organic residues by the oral microorganisms [ 4,5$]$, especially in cases where patients are wearing prosthetic restoration [6-10] or orthodontic devices [11,12] that hold organic residues. In the 70s the main causes of halitosis was discovered as representing the sulphuric volatile components (VSC) and in the year to come other instruments were devised by means of which direct identifications of VSC was possible( hydrogen-sulphuric, methanethiol and dimethyl-sulphuric) $[13,14]$. The organoleptic method is another way of measuring halitosis. It is a highly subjective method with very good quality results, but very poor quantity-wise since it manly depends on the olphactive acuity of the examiner. This is the main reason why objective instruments had to be developed, at the moment halimeter and BANA test being the most widely used [1]. Oral malodour can be caused by the pathology of the oral cavity such as dental caries, causing tongue, expose dental pulp, food impaction, periodontal diseases, alterations or oral cancers. The main factor in halitosis is bacterial as Cocci and Gram-negative anaerob bacili have VSC as final metabolic products $[1,15]$. Oral malodour is a condition with a high social impact, eighteen million people suffering from it over to million dollars being spent annually on products attempting to disguise the embarrassing small [2].

The aim of this study is to extend research on the effect of various mouthwashes on oral malodour and also on periodontal status, since most of the time halitosis is connected to periodontal disease. The paper also aims at evidencing the possibilities of using BANA test as means of diagnosis in oral malodour and of early stages of periodontal disease.

\section{Experimental part}

Materials and methods

Subjects: 26 patients with special needs aged between 16-45 were enrolled in the study. All of them had corresponding oral hygiene with more than $10 \%$ of the site showed plaque index 1 and gingival index 1 , all of them with halitosis. None of the patients had used antibiotics for the previous four weeks, were not subjected to orthodontic treatment and did not showed any systemic diseases at the moment of the investigations. None of the patients was smoker or presenting scrotal tongue. Informed consent was obtained after clear explanation of the stages of the study and its aims. The 26 patients were randomly divided in 2 groups of 8 subjects: control group and test group.

\section{Clinical examinations}

The periodontal status was recorded after Ramfjord, which include the maxillary right first molar, the maxillary left central incisor, the maxillary left first premolar, the mandibular left first molar, the mandibular right central incisor, and the mandibular right first premolar. The following parameters were assessed: bleeding on probing by using a probe, probing depths (PD), and clinical attachment level (CAL). The presence or absence of plaque was evaluated with plaque index [16]. Gingival inflammation was assessed by the gingival index [17]. Oral malodour was subjectively assessed by the examiner both organolepticaly. Breath odour examinations was carried outobjectively and subjectively. The patients was instructed not to use onion, garlic, spicy food, alcohol, or smoke 48 hour prior to examination, and not to use chewing gum, mouthwash or any other substance that could disguise halitosis prior to examination. Objective examination (ORGO) was carried out by the same calibrated dental examiner so that the subjective perceptions would not modified the values in the test. The examiner had a normal 
sense of smell and did not intake alcohol, coffee, tea or cigarettes prior to examination. Perfumed cosmetics were avoided. The examination took place in the dental medicine surgeryand the subjects were instructed to keep the mouth completed close for 3 min while breathing through the nose only. After 3 min they were intrusted to slowly release the air through the mouth and $10 \mathrm{~cm}$ from the nose of the examiner who graded the smell on a scale from 0 to 5 .

BANA tests(N-benzoyl-DL-arginine naphthylamide), describe by Loesche et al. [18], is a rapid test for evaluation of non-sufuros compounds. BANA tests were used to evidence the three bacterian species, Porphyromonas gingivalis, Tannarella forsythia, Treponema denticola, which can be felt responsible for halitosis because of their proteolotic activity. These microorganisms release an enzyme able to hydrolyze the synthetic peptide benzoylDL-arginine-naphthylamide (BANA) on the testband. When either or all three species are present on the sample from the dorsal side of the tongue, BANA is hydrolyze, the test reads positive and the index became blue. The bluer the color, the higher the bacterian concentration. As BANA test are sensitive to light and humidity, they will be taken out the box only prior to use and the box be seal back. The upper part of the band provides place for name and data examination. The samples from the dorsal site of the tongue was taken on a cotton swab then place on the marked lower part of the BANA band. After placing it, the upper part of the test which is pink-orange is dampened with distilled water by means of sterile swab. Care should be taken not to used to much water since it can dilute the reactive and induce a false negative response. The test is then folded on the dotted area so that the side containing the reactive will came in contact with the side with the sample from the tongue. The folded test is next introduce in a incubator in $55 \mathrm{C}$ for $5 \mathrm{~min}$, after which is it taken out, cut on the dotted line and the upper part of the test, with the reactive is examined. The results were logged in accordance with the blue zones as per manufactures instruction. The card contains three codes: Negative - no color changes; Slight positive - light blue dots randomly spread on the band; Positive - dark blue patches on light brown test band. The control mouthwash was distilled water for placebo, and the test mouthwash had the following recipe: distilled water, essential oil of lemon, essential oil of meant, Natrium dicarbonate. After examination of the subjects, registering the organoleptic scores and the BANA test results, the patients were examined and instructed on the correct techniques of the brushing and the cleaning the mouth. The subjects received the same type of tooth paste and the same amount of mouthwash according to the group: control group placebo mouthwash and test group - test mouthwash. The mouthwash was used twice daily for 28 days.

\section{Statistical analysis}

The Statistical Package for Social Sciences (SPSS) was used for data processing and statistical analysis. The MannWhitney $U$ test was used to analyze the difference between groups.

\section{Results and discussions}

The present paper evidences the effect of essential oil mouthwash on oral malodour, plaque index, bleeding on probing index, bacterian concentration and organoleptic examination carried out by both examiner and subject. The initial results showed significant changes after treatment, with a dramatic difference in the test group regarding the plaque index, bleeding on probing, gingival index, BANA test results and organoleptic examinations values.

The plaque index showed significantly higher changes in the test group as compared with the control group. Prior the treatment, the control group (Fig. 1) had an average plaque index in all subjects of 1.273 , and after treatment it decreased to 1.021 , which represents merely $9.25 \%$ $(p<0.05)$.

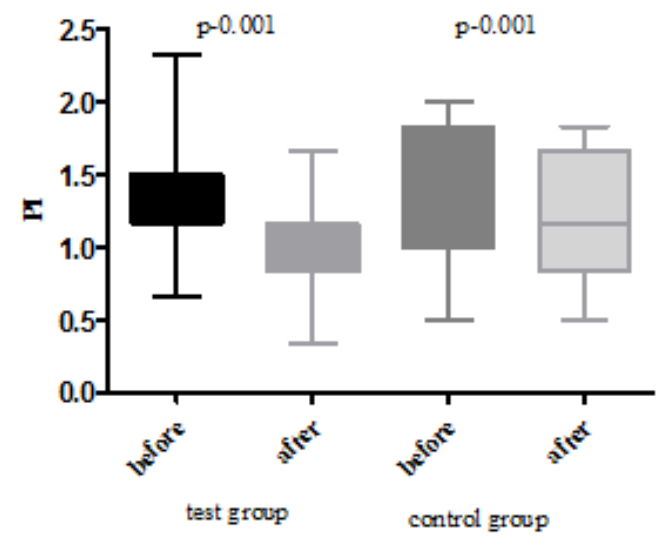

Fig. 1. Plaque index before and after treatment in both group (test group and control group)

The difference could be due to the higher attention to oral hygiene during the study. The test group (Fig. 2) showed a decrease in the plaque index of $28.3 \%$, from 1.146 before treatment to 0.898 after the treatment $(p<0.05)$. Bleeding on probing showed positive results after treatment in the control group with a difference of 5.32\% compared to baseline and a difference of $33.37 \%$ compared to the baseline in the test group. Our observations demonstrate the adjuvant effect of antimicrobian mouthwash with essential oils combined with correct brushing on adequate oral health with PI and BOP of 0 or 1 (Fig. 2).

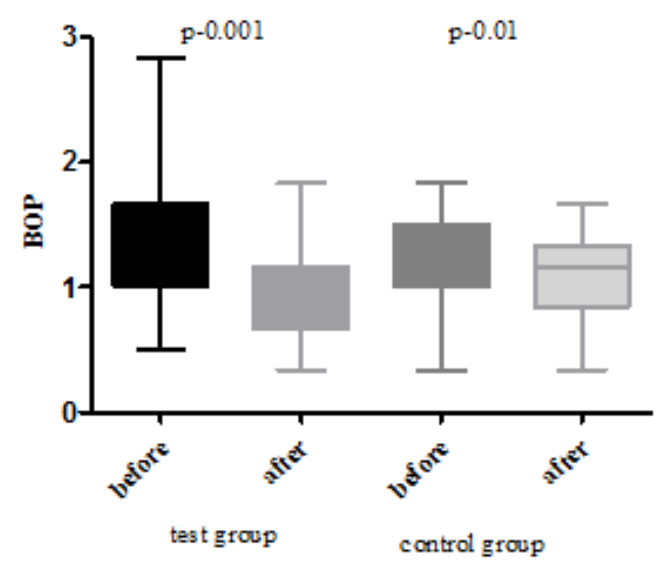

Fig. 2. BOP before and after treatment in both groups (test group and control group)

BANA test evidenced three anaerobe bacteriae acting on the periodontium and bad breath. In the control group the results of the test decreased by $3.68 \%$ while in the test group the decrease was more significant of 33.09\% (Fig. 3).

The objective organoletic examination showed an improvement in the subject's breath, more dramatic in the test group. After 28 days the scores in the control group decreased by $7.38 \%$ and in the test group by $44.65 \%$ ( Fig. 4).

The aim of this study is to evaluate the effect of essential oil mouthwash on halitosis and periodontal status of patient with special needs. Halitosis is an embarrassing symptom 


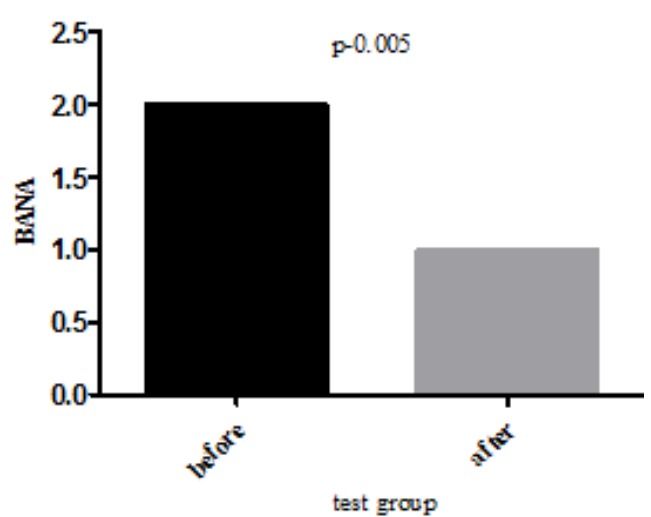

Fig. 3. Changes in BANA test before and after treatment in test group

with a significant social impact. Periodontal disease, tongue coating, interdental food impaction, dental cavities are the predominant causative factors. BANA test is efficient in the periodontal diagnosis. The test detect the red complex species [5].

In the present study, BANA test showed significant associations in all periodontal parameters. Bleeding on probing, gingival and plaque index were found to be significant with BANA. Puscasu et al. [19] observed a statistical correlation with the severity of periodontal status and BANA. Asokan et al. [20] investigated the effect of oil pulling with sesame oil on halitosis and the microorganism responsable for it. Their studyshowed equally efective like chlorhexidine againsthalitosis. The finding of present study were similar regarding the beneficial effects of essential oil mouthwash on the clinical and microbiological parameters of periodontal inflammation. Other studies on antibacterian properties of the essential oil obtained similar results showing an improvement of $26 \%$ in the test group scores as compared with the control group scores [21]. The association of essential oil with mounthwash has shown to be effective antiplaque agent. Ross et al. [22] showed that essential oils annihilate microorganisms in the presence of serum.

The results of our study provides a statistically significantly greater level of efficacy on periodontal status, in controlling established halitosis, plaque and gingival index after use the essential oil mouthwash.

\section{Conclusions}

The evaluation of the results confirmed the work hypothesis that is the essential oil have a benefic clinical effect on oral malodour and periodontal parameters. The presentstudy contain practical implication and can be used whenever patients ask for help with their oral hygiene and breath bad. A preventive strategy, including oral hygiene instructions and proper management of the periodontal status is needed in order to improve patient's general health and social life.

\section{References}

1.DE BOEVER, EH, LOESCHE, WJ (1995), J Am Dent Assoc.; 126(10):1384-93.

2.ONGOL, R, SHENOY, N (2010), Kathmandu University Medical Journal, Vol. 8, No. 2, Issue 30, 269-275.
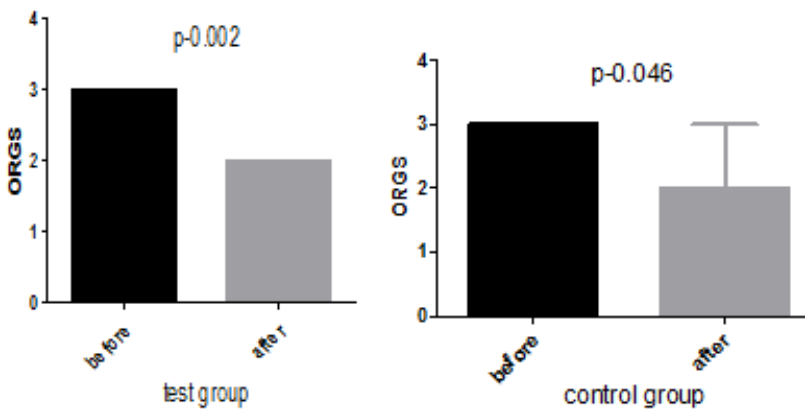

Fig. 4. Changes ORGS in the test group and control group

3. GROVER, HS, BLAGGANA, A, JAIN, Y, SAINI, N. Contemp Clin Dent. 2015; 6(Suppl 1):S181-S187. doi:10.4103/0976-237X.166825

4.CIAVOI, G., TIRB, A, BECHIR, E.S., BECHIR, F., SUCIU I., Rev. Chim. (Bucharest), 69, no.10, 2018, p. 2648.

5.ODOR, A.A, BECHIR, E.S, VIOLANT, D., BADEA, V., Rev. Chim. (Bucharest), 69, no.8, 2018, p. 2081.

6.HANCU, V., COMANEANU, R.M., COMAN, C., FILIPESCU, A.G., GHERGIC, D.L., COTRUT, M.C., Rev.Chim. (Bucharest), 65, no. 6, 2014, p. 706-709.

7.COMANEANU, R.M., HANCU, V., BARBU, H.M., COMAN, C., COTRUT, C.M., TARCOLEA, M., HOLICOV, A.M., ORMENISAN, A., Rev.Chim. (Bucharest), 66, no. 3, 2015, p. 312-315.

8.HANCU, V., COMANEANU, R.M., COMAN, C., TARCOLEA, M., BARBU, H.M., BECHIR, A., MICULESCU, F., LOREAN, A., Rev.Chim. (Bucharest), 66, no. 9, 2015, p. 1327-1330.

9.COMANEANU, R.M., HANCU, I.D., COMAN, C., HANCU, V., BARBU, H.M., COTRUT, C.M., CERNUSCA MITARIU, M., MARIS, M., Rev.Chim. (Bucharest), 67, no. 10, 2016, p. 1940-1944.

10.TARCOLEA, M., HANCU, V., MICULESCU, F., SMATREA, O., COMAN, C., COMANEANU, R.M., ORMENISAN, A., Rev.Chim. (Bucharest), 66, no. 8, 2015, p. 1143-1146.

11.BECHIR, A., PACURAR, M., BECHIR, E.S., COMANEANU, R.M., CHIBELEAN CIRES, M., MARIS, M., BARBU H.M., Mat. Plast., 51, no. 1, 2014, p. 57-61.

12.BOTOACA, O., BECHIR, E.S., COMANEANU, R.M., COMAN, S., TARCOLEA, M., DRAGUS, D., Rev.Chim. (Bucharest), 70, no. 1, 2019, p. 84-86.

13.*** ADA Council on Scientific Affairs. Oral maladour (2003), J Am DentAssoc.; 134(2):209-14.

14.MIYAZAKI, H, ARAO, M, OKAMURA, K, KAWAGUCHI, Y,TOYOFUKU, A, HOSHI, K, YAEGAKI, K (1999), Niigata Dent J, 32:7-11.

15.MENINGAUD, JP, BADOF, FAVRE, E., BERTRAND, JC (1999), Rev Stomatol Chir Maxillofac, 100:240-4.

16.0'LEARY, TJ, DRAKE NAYLOR, JE (1972), J Periodontol 43, 38.

17.LOE, H, SILNESS, J, (1963), Acta Odontol. Scand, 21: 533-551.

18.LOESCHE, WJ, GIORDANO, J, HUJOEL, PP (1990), J of DentaResearch, 69(10):1696-1702.

19.PUSCASU, CG, DUMITRIU, AS, DUMITRIU, HT (2006), J of Oral Health and Dental Management, 5(3):31.

20.ASOKAN, S, KIMAR, S, EMMADI, P, RAGHURAMAN, R, SIVAKUMAR, N (2011), J of Ind Soc of Pedod and Prev Den, 2(29):90-95.

21.CHARLES, C (2013), General Dentistry, Jan/Feb; 23-28.

22.ROSS, NM, CHARLES, CH, DILLS, SS (1989), J Clin Dent, 1(4):92-5.

Manuscript received: 10.01 .2019 